\title{
Autoridade e afeto em relatos de bullying: notas sobre a percepção dos professores
}

\author{
Maria Claudia Coelho' \\ Johana Pardo²
}

\section{Resumo}

O artigo examina a percepção de professores de escolas públicas do Rio de Janeiro sobre episódios de bullying. Dialogando com a perspectiva teórica que propõe o tratamento da violência como uma categoria êmica, a análise examina a existência de um "deslizamento semântico" entre as categorias "bullying" e "violência". O foco está no problema do exercício da autoridade docente nesse contexto. Os dados analisados são um conjunto de 11 entrevistas em profundidade realizadas com professores da rede pública do Rio de Janeiro. Na conclusão, retomamos formulações da teoria social clássica, em particular as obras de Max Weber e Bronislaw Malinowski, para explorar a forma como o exame do exercício da autoridade docente diante de episódios de bullying pode contribuir para a percepção da relação entre o afeto e a autoridade.

Palavras-chave: bullying; autoridade; afeto; violência nas escolas

\section{Authority and affection in narratives about bullying: notes on teachers' point of view}

\section{Abstract}

This paper analyzes how teachers from public schools in Rio de Janeiro describe and comment on episodes of bullying. Based upon a theoretical perspective that advocates for the understanding of "violence" as an emic category, analysis approaches the existence of a "semantic displacement" between "bullying" and "violence". Its focus is on how teachers impose their authority in these contexts. Data is a set of 11 in-depth interviews conducted with teachers from public schools in Rio de Janeiro. Classical theories on authority, such as Max Weber's and Bronislaw Malinowski's works, are referred to in the final remarks in order to explore the way teachers' strategies to enforce their authority when confronted with bullying episodes may contribute to the deepening of the understanding of the relations between affection and authority.

Keywords: bullying; authority; affection; school violence

\section{Introdução ${ }^{3}$}

1 Professora Titular do Departamento de Antropologia do Instituto de Ciências Sociais da Universidade do Estado do Rio de Janeiro (UERJ)

2 Doutora em Ciências Sociais pelo Programa de Pós-Graduação em Ciências Sociais (PPCIS) da Universidade do Estado do Rio de Janeiro (UERJ)

3 Uma primeira versão deste texto foi apresentada na 31ª Reunião Brasileira de Antropologia (Brasília, dezembro de 2018). A discussão aqui apresentada traz resultados do projeto "Interação e Gramáticas Emocionais: o fenômeno do bullying", apoiado pelo Programa de Bolsas de Produtividade em Pesquisa do CNPq e pelo PROCIÊNCIA/UERJ. 
Em texto seminal de revisão bibliográfica sobre o campo de estudos da violência e da criminalidade, Zaluar (1999) aponta para as imprecisões conceituais do termo "violência". Para a autora, haveria diversos sentidos possíveis para o termo "violência" nesse campo de pesquisa, ora designando todas as lacunas de atendimento nos serviços públicos (entendidas como "violência perpetrada pelo Estado"), ora se referindo ao "poder militar abusivo e ilegítimo" (1990: 10). O conceito de "violência estrutural" concorria também para reforçar esse emaranhado conceitual: "a dificuldade principal desta abordagem é que violência tornase um sinônimo de desigualdade, exploração, dominação, exclusão, segregação e outros males usualmente associados à pobreza ou a discriminações de cor e de gênero" (1990, p. 11). Haveria ainda, também seguindo Zaluar, uma outra malha semântica em torno das fronteiras entre violência e poder, acompanhando Hannah Arendt e suas reflexões sobre relações de poder e usos da linguagem, com suas implicações sobre a alteridade.

O problema da violência enquanto categoria êmica - ou, na feliz formulação de Éric Debarbieux, "aquilo que eu considero como tal" (2001: 177) - suscitou algumas reflexões que são hoje referências consagradas nas Ciências Sociais brasileiras, tais como a questão das dimensões física e moral da violência (CARDOSO DE OLIVEIRA, 2002) ou o problema da compaixão (SOARES e CARNEIRO, 1996). Explorações etnográficas dessa problemática - o conceito de violência versus suas definições êmicas - podem ser encontradas, por exemplo, no trabalho de Simião (2006) sobre a construção da categoria "violência doméstica" no Timor-Leste ou na análise de Coelho (2009) sobre percepções femininas da violência.

A problemática das definições êmicas da violência, com suas implicações teóricas e metodológicas, foi explorada no contexto específico da violência nas escolas por Éric
Debarbieux (2001). Discutindo a emergência da violência nas escolas como um objeto demarcador de um campo de estudos com contornos precisos na França, o autor expõe as dificuldades conceituais aí encontradas:

Em outras palavras, há um erro fundamental, idealista e ahistórico, em acreditar que definir a violência, ou qualquer outro vocábulo, consista em se aproximar o mais possível de um conceito absoluto de violência, de uma 'ideia' da violência que, de fato, tornaria adequados a palavra e a coisa. 'Definir' a violência na escola é, antes, mostrar como ela é socialmente construída em sua própria designação, como seu campo semântico se amplia a ponto de se tornar uma representação social central. Que fatos sociais heterogêneos sejam reunidos sob o termo genérico de 'violência' pelos atores da escola é em si mesmo um fato social digno de ser pensado. (DEBARBIEUX, 2001, p. 164)

Debarbieux retoma diversas formas de esmaecimento das fronteiras conceituais entre a violência nas escolas e outros fenômenos encontrados no cotidiano escolar, tais como o conceito durkheimiano de anomia e o turvamento da distinção entre "violência" e "bagunça", ou o conceito de Pierre Bourdieu de "violência simbólica". Advogando uma abordagem da violência em termos êmicos, o autor expõe assim sua visão:

\footnotetext{
"Não se trata aqui de uma posição subjetivista e solipsista, mas de uma tentativa de agrupar segundo categorias sociais e ordenações institucionais os fatos qualificados de violência pelos próprios atores sociais que os sofrem, os operam ou são deles testemunhas (...). A variabilidade dessas qualificações é significativa, elas diferem tanto entre alunos e docentes quanto entre docentes e administração, por exemplo (...). Entretanto, se, por um lado, todos os atores aceitam considerar as violências em termos de Código Penal, por outro lado, é certamente sobre as violências pequenas,
}

3 Constituem o uso de medicamentos para uma indicação não aprovada, um grupo etário não aprovado, uma dose não aprovada ou uma forma de administração não aprovada, de acordo com o registro sob o qual um fármaco é licenciado no órgão sanitário competente (FREITAS; AMARANTE, 2015). 
cotidianas, que o debate é mais vivo, em torno da noção de incivilidade. De fato, as pesquisas de vitimação demonstram que, se um número não derrisório de alunos e docentes são vitimados, na imensa maioria dos casos o que é considerado como violência não emerge meramente do Código Penal, mas se agrupa sob as categorias cômodas da 'violência verbal', ou até mesmo simplesmente do 'clima' ou da 'falta de respeito"'. (DEBARBIEUX, 2001, p. 177-78)

Em projeto de pesquisa voltado para a análise da violência nas escolas do Rio de Janeiro, encontramos uma problemática de natureza bastante semelhante: a mescla entre "indisciplina" e "violência" nas narrativas solicitadas a professores (BOMENY, COELHO e SENTOSÉ, 2010). A essa mescla nos referimos então como um "deslizamento semântico", cujo ponto de contato pareceu-nos ser, naquele contexto, o desafio que ambas colocavam ao exercício da autoridade docente, colocando em xeque a própria construção da identidade profissional do professor.

Nesse artigo, revisitamos esse problema em uma nova configuração: um "deslizamento semântico" entre a violência nas escolas e o bullying. Segundo Rolim (2008), o bullying teria, em sua definição, três componentes básicos, de acordo com a Associação Médica Americana (AMA):

“1) Um comportamento agressivo intencionalmente voltado à imposição de sofrimento por uma pessoa ou grupo;

2) Um comportamento oferecido de forma repetida e insistente contra as vítimas;

3) Um comportamento entre pares que vitima as pessoas que possuem menos poder." (ROLIM, 2008, p. 15-16)

O foco do texto é discutir o lugar da autoridade nessa trama conceitual urdida em torno das concepções êmicas de violência, indisciplina e bullying, com atenção particular para o papel desempenhado pelo afeto no exercício da autoridade.

Os dados analisados são um conjunto de dez entrevistas em profundidade com professores versando sobre episódios de bullying presenciados, com foco nas estratégias utilizadas para lidar com eles e nos sentimentos suscitados nos entrevistados. Recorremos também a uma entrevista realizada no âmbito do projeto "A Violência nas Escolas do Rio de Janeiro: dimensões do problema e percepção pela comunidade escolar" ". São três os pontos examinados: a) a trama conceitual entre as noções de "violência", "indisciplina" e "bullying"; b) os recursos acionados para lidar com o bullying; e c) a emergência de uma "figura narrativa" chave nos relatos: o aluno-agressivo-domado-pelaconversa.

Nas considerações finais, discutimos de que modo esse exame da autoridade docente face aos fenômenos do bullying e da violência nas escolas pode contribuir para uma retomada da discussão, tão central nos clássicos da teoria social, sobre a relação entre autoridade e afeto. $\mathrm{O}$ ponto estará na problematização da dissociação entre ambos, tomando o exercício da autoridade docente como um caso em que a autoridade se exerce através do afeto, seja como sua motivação, seja como seu instrumento.

\section{Uma trama conceitual: violência, indisciplina e bullying}

A pergunta central do nosso roteiro pedia que o entrevistado relatasse episódios de bullying que tivesse presenciado em sua sala de aula ou sua escola. De saída, chamou-nos a atenção uma marca recorrente na forma de relatar esses episódios, muitas vezes precedidos de negativas variadas quanto à sua relevância ou mesmo existência.

Uma primeira negativa afirma ser o bullying um problema "menor" diante de outros

4 Esse projeto foi realizado em 2007-2009 com apoio da FAPERJ, sob coordenação de Helena Bomeny e participação de Maria Claudia Coelho e João Trajano Sento-Sé como pesquisadores. Agradecemos aos colegas Helena Bomeny e João Trajano Sento-Sé a autorização para utilizar aqui essa entrevista. 
problemas que marcariam o cotidiano escolar em escolas da "periferia":

Infelizmente a questão do bullying, ela está diminuída em relação aos problemas e aos enfrentamentos e aos desafios da violência do próprio ambiente que é muito mais agressivo que o próprio, que o próprio bullying. $\mathrm{Na}$ escola da periferia, o bullying, eu acho, é o menor dos problemas. Eu estou sendo sincero. (...) Porque o bullying, na minha opinião, na minha opinião, não pesquiso violência escolar, eu sou afetado por ela, mas o que eu penso, na minha reflexão, eu acho que o bullying é o menor dos problemas pros enfrentamentos que temos diante aí, diante de termos violência, da violência de acontecer ontem, por exemplo. De um aluno arriar a calça e estar de cueca no meio da sala de aula. (Entrevista 6)

\section{O mesmo entrevistado afirma explicitamente} que o bullying não seria uma "grande questão" diante das "violências" e dos "problemas sociais", estas sim responsáveis pela evasão, entendida de modo mais amplo como uma espécie de "descrédito da educação":

(...) na verdade a evasão, pelo bullying, eu acho que não é uma grande questão. A grande questão é o problema social que faz com que as pessoas saiam da escola. E aí é problema social mesmo, é a necessidade do trabalho, que empurra as pessoas pro trabalho e dificulta a vida... a vida escolar, né? São as violências, aí, é... (pausa) é... de vida, né? Que a pessoa... a dificuldade de vida. Violência que eu falo aí é a dificuldade que a pessoa enfrenta num mundo cão, né? (...) Pior que o bullying, entendeu? Acho que tudo... essa questão da violência é que faz com que a pessoa deixe a escola. Por que? Porque o bullying... se uma pessoa está triste porque uma pessoa está triste porque não foi aceita por aquele grupo, ela vai mudar de escola. Mas a evasão mesmo, a evasão, de deixar de estudar e de... e de... deixar de estudar também acontece por conta de não acreditar na potencialidade que a educação pode promover de transformação. E aí o que eu acho que tem acontecido é que o estado promove uma política violenta contra as populações. (Entrevista
6)

Outras entrevistadas explicitam a dificuldade de se perceber a ocorrência de bullying em sala de aula:

Muitas vezes o bullying acontece a gente nem percebe, porque às vezes é uma implicância que é feita quase que sussurrada, não é algo que é gritado para que todo mundo ouça, muitas vezes é aquela implicância que chega apenas no ouvido da pessoa. Então em uma sala de aula com uma turma de 40 alunos é difícil você perceber quando está acontecendo. A gente consegue sentir alguma coisa tá errada, por exemplo, quando um aluno mesmo tem essa iniciativa, ele diz "olha a professora fulano tá falando isso, assim assado de mim" (...) (Entrevista 2)

Nesses casos não dá para perceber porque assim, não foi um caso, essa turma, que eles pegavam a pessoa, não, é um caso de agressividade coletiva, eu não sei se chega a ser o bullying, eles são agressivos entre eles, eles são agressivos com os professores, eles fogem ao, sei lá, a toda, tudo que a gente tenta fazer ali dá errado, visivelmente errado. (Entrevista 1)

\section{E você já presenciou algum caso de bullying?}

Então, eu leio um pouquinho sobre esse negócio. E, assim, é difícil de você definir bem o que que é bullying, diferenciar bullying de violência, de incivilidade, de indisciplina. É... na sala de aula a gente ouve os alunos o tempo todo falando sobre bullying: "olha professor, ele praticou bullying comigo". Mas muitas vezes... a gente ouve isso na sala dos professores também. Mas muitas vezes a gente, a partir das leituras que eu tenho, né, a gente vê que o termo é meio que jogado aos quatros ventos, quatro cantos, sem noção muito do que significa. Bom, dentro do que eu acho que seja bullying, se eu vejo isso, sim, vejo isso na sala de aula. Na rede pública, municipal, né, a gente tem muitos problemas, é... desse tipo de... de ofensa, de... de um aluno contra o outro, de um grupo contra um aluno, é... então sim, me deparo com isso, por vezes, mais de uma vez no dia, assim. (Entrevista 9) 
Os relatos suscitados apareciam também mesclados a episódios que, de um ponto de vista conceitual estrito, não poderiam ser considerados bullying (tal como definido pela literatura especializada, de acordo com o exposto por Rolim [2008]), gerando, assim, a necessidade de recorrermos à perspectiva já comentada de Éric Debarbieux, acerca da violência nas escolas, de se atentar para a dimensão êmica da noção de bullying. É assim que surgem relatos de episódios de bullying sofridos pela professora entrevistada quando era aluna:

Como você se sente quando vê uma agressão assim de bullying?

Eu fico muito irada, é uma coisa que mexe muito comigo, porque eu sei o que eu sofri, eu sofri de diversas formas, não só verbal, como física também e assim era gratuita não tinha absolutamente nada que justificasse agressão. (Entrevista 2)

Já teve alguma situação em sala de aula que tenha mexido emocionalmente com você?

Então, esse caso aí, esse caso me tocou bastante, porque me toca diretamente a questão da negritude, foi a primeira vez que eu presenciei um caso de racismo e por mais que o aluno tenha se arrependido, ter negado o fato, de dizer que ele não era racista ele assumiu que fez, mas mesmo assim ele quis enfatizar que ele não era racista, mesmo assim foi algo que me tocou, porque de onde vem esse discursos que chegam na boca de um adolescente? Vem de algum lugar, então, está na sociedade, um outro que me toca diretamente, é a questão da sexualidade, né, quando alguém é ofendido pela sua sexualidade, isso me toca, porque eu sou homossexual, isso me toca diretamente porque eu sofri com isso a vida inteira, na escola, né, a escola foi um lugar de opressão para mim, então ver isso como professor é muito cruel, que hoje eu falo de outro lugar eu sou adulto, sei lidar com isso, e eles? (Entrevista 4)

Surgem também, nesse contexto de entrevistas sobre bullying das quais participam como professores, histórias de agressões sofridas por eles mesmos enquanto professores, ou seja, já não mais histórias de bullying que teriam sofrido em outros momentos de suas biografias, como estudantes, mas histórias de agressões por parte de seus alunos de que são alvo, como no caso de uma entrevistada que emenda comentários sobre agressões ocorridas entre os estudantes com agressões cometidas pelos mesmos contra ela:

Eles eram bem agitados e a maior parte deles tinha uma atitude bem agressiva um com o outro mesmo, aquilo que eu falei, um cortou o cabelo já ia zoar o cabelo do outro de falar coisas, assim, agressivas, né! Eles chegaram a falar coisas agressivas para mim.

E tinha pessoas... o que falavam agressivo para você? (...)

É, eu vou falar, mas assim é aleatório demais, porque eles fazem isso por fazer, não é, você vê que não é... Ah, o aluno falou para mim que o meu bebê ia nascer morto (risos), um aluno dessa turma. Estava todo mundo aí eu cheguei, aí eles falaram "ah tá grávida", não sei o que, aí ele virou para mim e falou "o seu bebê vai nascer morto" (risos). Aí então é o que eu estava falando, eles têm uma postura agressiva entre eles, com os professores (...) (Entrevista 2)

Mas você estava falando que o bullying era bilateral...

Sim, sim, eu falei, a criação influencia muito nesse aspecto, muitos alunos veem o professor como um inimigo, né ou como alguém a ser combatido. Eles não têm a menor ideia do porquê eles fazem isso, é um comportamento que vem sendo reproduzido, reproduzido, reproduzido, reproduzido... Sei que muita gente não gosta quando falo isso, mas eu acho que é um comportamento que é muito dessa pedagogia de Paulo Freire que para mim é uma pedagogia completamente distorcida, em que coloco o aluno como um oprimido, e o professor com um opressor ,eu não vejo isso eu vejo isso, eu vejo o professor e aluno como equipe, sendo que cada um desempenha seu papel, então eu nessa escola municipal que inclusive eu não trabalho mais, eu pedi exoneração, porque eu não aguentei, eu não aguentei, o fato é esse, eu vi que ia ficar doente, e é justamente sabe, ou ficar realmente ou estressado ou deprimido ou alguma coisa, eu não aguentei o tranco e eu pedi exoneração, por 
exemplo casos que aconteceram comigo, ah, vai ter um café comunitário na sexta feira cada um traz uma coisa, tudo bem, tá ótimo.

Na escola pública?

Nesse caso foi a escola pública, e muitos alunos vieram com muita piadinha sem graça do tipo, (o entrevistado representa o aluno) "professor vai botar salsicha na boca", sabe, essas piadinhas de duplo sentido que eles sabem muito bem o que eles estão fazendo (...) (Entrevista 3)

Uma última razão para a dificuldade de se obter relatos de bullying entre os professores entrevistados diz respeito exatamente àquilo que o bullying parece colocar em xeque do ponto de vista dos professores: a autoridade docente. É, assim, o seu exercício preventivo que explica a recorrência da negação de sua existência. $\mathrm{Na}$ fala de uma entrevistada:

Não, na minha sala isso não acontece, eu sempre evito que até comece quando alguém começa a falar alguma coisa falo "para, parou aí", para que não comece. Então eu já aviso logo não vou admitir isso aqui antes mesmo das aulas começarem, sistematicamente, eu já aviso "olha só, uma coisa que eu não admito em sala de aula é bullying, não admito" e digo para eles eu sofri bullying na minha infância inteira, eu sei muito bem como eu me senti, então eu não quero que isso aconteça aqui. Não quero ninguém sendo agressor e ninguém sendo agredido, não quero piada, não quero apelido, nada que esteja ofendendo o outro, porque se o outro está sentindo ofendido, eu não quero. (...) Eu sempre tento nesse sentido, então comigo, efetivamente, nesse sentido, nunca aconteceu. Nesses 18 anos aí que eu estou em sala de aula pelo menos eu consigo evitar qualquer tipo de agressividade, que ela comece, então a coisa já acaba por aí. (Entrevista 2)

Então assim, lembrar mesmo eu não me lembro de nada que tenha me chamado atenção, porque como eu falei, eu não permito que aconteça, assim que começa eu já paro e falo "acabou, não vai acontecer nada", porque se continuar desse jeito a gente vai ter um problema seríssimo aqui dentro, e aí eles ficam com medo e param, porque eles percebem que eu estou falando muito sério que eu não quero que isso aconteça. (Entrevista 2)

Cabe agora, então, examinarmos como os professores lidam com esses episódios.

\section{Os matizes do exercício da autoridade: da conversa às regras e de volta à conversa}

Diante de episódios de bullying/ indisciplina/ violência, os professores elencam diversas estratégias a que podem recorrer para lidar com a situação. Essas estratégias formam um continuum, uma espécie de gradação que percorre o regimento escolar, acompanhando suas normas, sua hierarquia e sua atribuição de funções. Parecem, contudo, operar em dois registros: um primeiro, formal, característico daquilo a que Weber (1999) se referiu como "autoridade institucional" (ou "dominação burocrática”), e um segundo, de natureza afetiva, acionado ora como primeira, ora como última instância, alternativa final uma vez esgotados todos os recursos regimentais. Listamos a seguir alguns fragmentos nos quais essa trajetória percorrida pelos esforços de exercício da autoridade aparece (os grifos visam realçar o que será discutido adiante):

Então eu acho que a gente sempre tem um caminho que se pode ser percorrido, para evitar que essas coisas aconteçam, (...) que eles nos falem para que a gente possa buscar uma solução que, realmente, para essa situação. Porque se eles ficarem no revide não vai parar, então a gente tem que tentar fazer com que eles percebam que há alguém acima deles que vai tentar resolver essa situação da melhor maneira possível, e se o caso for muito gritante a gente aplica o regimento da escola. $\mathrm{O}$ aluno que é excessivamente agressivo e se não deu jeito na conversa, se a família não conseguiu resolver, a gente vai aplicando o regimento: troca de turma, troca de turno, ou troca de escola. Então a gente vai procurar um meio para que esse indivíduo entenda que ele não tem que ser agressor, a gente sempre procura a socialização mesmo, a inserção mesmo do indivíduo, não exclusão. (Entrevista 2) 
Então... aí eu tive que suspender a aula. E o aluno não foi suspenso. Não foi suspenso. Sim, foi advertido, chamou a pessoa da administração chamou para conversar e tal, chamou hoje porque ele fugiu. Ainda por cima ele invadiu a escola, porque não tem inspetor para segurá-lo, também não posso ficar mantendo uma pessoa. (...) Ele saiu e eu suspendi. E agora o que eu vou fazer, é uma medida, é que eu preciso fazer uma medida repressiva. Eu apesar de ser um cara democrático, liberal e tudo, mas eu vou ter que, vou ter que fazer uma medida repressiva de aplicar uma prova oral, de fazer ajustes, vou ter que reprimir na nota porque infelizmente porque porque vou ter que colocar aí uma prática educativa, vou dizer repressiva e tradicional, e fazer exigências e tudo. Porque o que acontece, eu estou sendo sincero, se ficar uma pedagogia muito livre, daqui a pouco eles estão me batendo e eu não tou sabendo reagir a isso, porque, porque isso chega até a mim, entendeu? (...) E aí eu trouxe essa portaria para a escola. (...) (Entrevista 6)

Já teve alguma situação de bullying em sala de aula que tenha mexido com você emocionalmente?

Não, o que eu sinto é efetivamente quando começa o bullying é essa raiva que vem porque eu me lembro do que eu passei, então primeiro sentimento é a raiva, “caramba porque que o cara está fazendo isso?", mas como a situação não cresce, ela não se torna insustentável, eu consigo dominar na conversa, evitar a partir dali, "não quero saber de bullying". Então eu nunca presenciei nada que fizesse, por exemplo, um aluno a começar a chorar em sala ou agredir o outro por conta disso, antes mesmo de começar eu falo "parou", para eles entenderem que ali não era o espaço para resolver dessa forma. E se fosse alguma coisa que eu percebesse que ali na sala de aula manter os dois ali quietos não ia adiantar de nada, eu tirava, chamava o inspetor ou a coordenação e explicava o que tinha acontecido, e pedia para alguém da direção conversar com aqueles dois alunos para tentar entender e fazer com que eles se entendessem também. (Entrevista 2)

Ajuda sim, porque a gente segue todos os trâmites, a gente fala o que é pra falar dentro da lei, a gente às vezes tem palestras e do pessoal da guarda municipal que chega pra explicar o que é tá acontecendo em relação à direitos deveres como aqueles devem ser comportar o que é que visa lei, o que diz o estatuto da criança de adolescente então a gente procura, sempre orientar, apresentar pra eles os direitos que eles têm e mostrar também os deveres que eles têm, a maneira como eles têm que se comportar, entender que ali na escola não é um espaço onde eles vão fazer acontecer, e que isso precisam respeitar aquele espaço e respeitar a si mesmos. (Entrevista 2)

Não, tratamento não. A única coisa que eu fiz foi conversar na sala. Parei a aula, né, pra a gente ter uma conversa, buscando a interação de todo mundo e tentando fazer, fazer com que eles entendam que as pessoas são diferentes, você tem que respeitar essa diferença, tanto religiosa, como de orientação sexual. (Entrevista 7)

Tem uma situação mais grave que tenha saído do controle?

Em meu caso não, porque você combate a confusão com serenidade, imagina está todo mundo gritando e você grita também, vira um manicômio, a sala de aula, ela perde completamente o contexto, vira um manicômio, assim, um bate no outro, todo mundo grita, você grita junto, quer dizer (...) você tem que ser firme, você tem que ser incisivo, fulano vem cá, não é gritar às vezes é você mudar um pouco o tom de voz, mostrar para o aluno que você está falando sério (...) (...) você imposta a tua voz, você projeta a tua voz, mas, mas sempre projeta no volume audível, no volume que dê para você se fazer, entender, num tom sério, mas sereno, eu acho que não dá pra combater confusão com confusão, grito com grito, o sucesso é zero (...) (Entrevista 3)

Como se pode notar, o espectro de medidas passíveis de adoção é amplo e inclui a conversa em várias instâncias (com a família, com a professora, com a administração da escola e até mesmo com a Guarda Municipal) e diversos tipos de medidas institucionais, previstas no regimento escolar (provas, suspensões, advertências) ou até mesmo portarias, ou seja, regras extrínsecas ao regimento da escola.

Chama a atenção, em particular, o status 
ambivalente ocupado pela conversa. Searle (1976) propõe uma taxonomia dos atos ilocucionários com base em seu ponto, ou seja, aquilo que o falante pretende produzir no mundo. O ponto ilocucionário, assim, pode ser a descrição de algo (atos representativos) ou a assunção de um compromisso (atos comissivos), entre outros. A categoria que nos interessa aqui é a dos atos diretivos, cujo ponto é, segundo Searle, "a tentativa do falante de conseguir que o ouvinte faça algo" (p. 11, tradução nossa). Entre os verbos que demarcam atos pertencentes a essa classe estão: pedir, mandar, ordenar, suplicar, implorar e aconselhar. Evidentemente, a força ilocucionária pode ser mais ou menos branda, como na diferença evidente entre pedir ou mandar que alguém faça alguma coisa.

Em outro lugar (COELHO, SENTOSÉ, SILVA e ZILLI, 2013), recorremos a essa classificação de Searle para discutir a forma particular do exercício da autoridade por outra categoria profissional: os policiais integrantes das equipes da Operação Lei Seca no Rio de Janeiro. $\mathrm{Na}$ análise ali empreendida, mostramos que a ênfase na polidez como estratégia de imposição da autoridade se apoiava em orientações e explicações, bem como em pedidos e convites, ao invés de ordens. Orientar, explicar, pedir e convidar compartilhariam, assim, o mesmo ponto ilocucionário - levar o ouvinte (no caso, o cidadão parado na blitz) a fazer algo, ou seja, acatar as normas da Operação Lei Seca (apresentar os documentos, soprar o bafômetro, etc) -, porém com força mais branda do que a proferição de uma ordem.

A ênfase posta pelos professores aqui parece cumprir uma função semelhante. Conversar com o aluno surge, em alguns depoimentos, como uma primeira estratégia de convencimento, de conseguir que faça algo (ou que não faça, o que talvez aqui seja mais adequado). $\mathrm{O}$ insucesso dessa estratégia daria então lugar a recursos mais incisivos, como o acionamento de mecanismos explícitos de sanção, seja da ordem dos atos de fala - as advertências - seja da aplicação de penalidades - a suspensão, a mudança de turma, a transferência de escola ou, no limite, a expulsão, cabendo até mesmo o acionamento de instâncias externas à escola, tais como a portaria ou a Guarda Municipal.

A conversa, contudo, parece passear por esse continuum. Se ora aparece como o primeiro recurso, a ser tentado antes das medidas mais severas previstas no regimento escolar ou mesmo na lei, também pode ocasionalmente ser definitiva - como no caso da entrevistada que afirma "dominar na conversa" ("antes mesmo de começar eu digo 'parou"') - ou, ainda, ocupar a outra extremidade do continuum, acionada diante do aluno de agressividade incomum, diante do qual todos os outros recursos falham.

É essa forma de exercício da autoridade, por meio da conversa, que examinaremos agora na figura de uma "função narrativa" recorrente nas entrevistas: o "aluno-agressivo-domado-pelaconversa”.

\section{O exercício da autoridade docente: afeto, conversa e confiança}

Nessas narrativas sobre o bullying, marcadas por negativas e evasividade, por vezes contraditórias, há um tema que emerge com clareza: a agressividade, em suas formas variadas, exercida pelos alunos entre si ou contra os professores. E, como em toda narrativa-padrão, essa também tem um "protagonista", uma espécie de "função narrativa" chave: o aluno-agressivodomado-pela-conversa.

E eu me lembro de uma outra aluna que eu tive, logo que eu iniciei no município, comecei no município uma das primeiras turmas que eu tive em 2002/2003, por aí que ela era um bicho do mato, ela era arredia e agressiva com todo mundo, ninguém se aproximava dela. Ela vinha com o cabelo dividido ao meio todo largado, ela não tinha nenhuma feminilidade, ela vinha como se fosse selvagem mesmo como se dissesse "não me toca", não encosta perto de mim", "eu não quero contato", e ela foi minha aluna por dois anos, foram dois anos seguidos, que eu dei aula para ela em sala. (...) E eu tentei ir na contramão disso, cada vez que era ela agressiva eu ia na docilidade cada vez que ela vinha 
na agressividade eu ia na docilidade, até num dado momento ela se modificou tanto, que nesse ano que ela não foi mais minha aluna ela passou a me procurar pela escola e ela vinha sempre com algum presentinho que ela tinha feito. (Entrevista 2)

Naquela pesquisa sobre violência nas escolas realizada há cerca de dez anos (BOMENY, COELHO e SENTO-SÉ, 2010), encontramos também esse personagem. Recorremos aqui a uma entrevista em particular do conjunto então realizado na qual há um pequeno e muito sugestivo elenco de histórias dessa natureza, ou seja, histórias de alunos e alunas descritos como muito agressivos, cujas revolta e agressividade teriam sido contornadas (contidas? controladas?) pela entrevistada por meio da conversa. Um exemplo paradigmático:

Ele era uma fera, uma fera dentro da sala.... fera de briga, assim uma fera mesmo. Irritadiço, tudo ele questionava, ele brigava com o professor, toda hora saía de sala. Aí eu passei a fazer o seguinte, sempre quando ele entrava ali eu dizia João, vem cá, vamos bater um papo. “Ah, eu vou pra aula”. Aí eu dizia, não vai pra aula hoje não. Eu dizia pra ele: eu te dispenso. Vem pra cá, eu te dispenso. Aí ele dizia: “tá bom”. Você vai subir, não vai aprender nada, não vai aprender coisa nenhuma, você vai pra lá e a tua professora vai se aborrecer, você vai agredir a tua professora, a tua professora vai agredir você. Então fica aqui comigo, vamos bater um papo. Aí eu começava: você viu o jogo? -não tinha nada a verVocê viu o jogo de vôlei? Você viu o jogo daquilo? Você sabe disso que tá acontecendo? Ou seja, tudo diferente de escola, de trabalho de casa. Nada tinha a ver com nada. Começou a ir lá. Aí ele fala: "ah! Puxa vida eu sou Fluminense e tal". Alguma coisa de interesse dele. Aí quando ele começava a relaxar ele dizia: "eu vou pra sala”. Aí eu dizia: não vai hoje não, amanhã você vai. Vai te embora, relaxa. (...) Esse menino então passou, quando ele chegava e a coisa não tava boa ele olhava pra mim com aquela carinha e dizia assim: "vamos bater um papo?” Aí eu largava tudo, porque eu largo tudo que tiver fazendo, e dizia: vamos conversar. Quantas vezes esse menino, tudo que acontece de bom com ele - ah, arranjei um emprego tal, tô fazendo um curso técnico não sei aonde - aí ele vem aqui e me fala. (Entrevista 11)

Dessa história retiramos o fio condutor do último ponto que gostaríamos de discutir aqui: o modo como autoridade e afeto se entrelaçam nessa forma de exercício da autoridade docente, por meio da conversa e da confiança. Para isso, reproduzimos inicialmente duas passagens de dois relatos distintos oferecidos na mesma entrevista. A primeira é uma história de uma menina descrita pela entrevistada como "altamente comprometida", e que insistia em tratar a professora como "tia":

E aí a tia, a tia sempre num sentido afetivo. Eu trabalhava - eu não sou a sua tia - então essa mudança de sou a sua tia é assim difícil de desligar. Mas no momento que ela diz: "tia, eu te amo”! Aí você diz assim: por que que você me ama? "Porque você fala com o coração". (...) Então aí você vê, você falou com o coração. Aí eu não sou a autoridade. Eu sou, eu fui na época, o vínculo de família que eles tanto precisam. (Entrevista 11)

A segunda passagem é retirada de uma história sobre um aluno sobre o qual só após algum tempo de convivência a entrevistada fica sabendo que frequenta a escola em situação de liberdade assistida.

"Ah, eu preciso conversar com você" (...). Larguei tudo pra conversar com ele. Uma hora conversando com ele e ele não olhava pra mim. Aí eu disse, você já percebeu - e aí eu olhei pro relógio- nós estamos conversando há uma hora e você não olhou nem um instante pra mim. Aí ele olhou, eu disse, bom agora eu vou falar o que eu estou sentindo: Ontem você agrediu a direção da escola, você não agrediu a professora Maria, você agrediu a autoridade que naquele momento eu estava representando. Aí ele abriu: eu tenho horror à autoridade. Eu disse: você tem horror à autoridade, então é porque na sua casa manda.....você é mandado em casa. Isso pra ele poder...eu queria exatamente que ele falasse, né, aí ele disse: é, isso mesmo; todo mundo resolve 
mandar, agora todo mundo manda, eu chego aqui e você manda. Quer dizer, não era a professora que ele estava vendo, ele estava vendo a autoridade. Ele disse: "eu não tenho nada contra você" - oolha só a duplicidade, né - "eu tenho contra a diretora". Quer dizer, ele separou, a diretora é uma pessoa a professora é outra. Aí eu comecei a conversar com ele e ele disse: "o juiz manda, a psicóloga manda, todo mundo manda”. Aí eu fui e disse, ninguém está te mandando aqui, nós estamos conversando (...) ele confiou, foi com uma confiança em mim, ele não precisava ter me contado. Aí eu disse pra ele: lá fora, o que se passou com você eu não vou tomar conhecimento, o conhecimento vai ser daquela porta pra cá e como eu vou te ajudar. O que eu vou fazer pra você melhorar em termos de educação, de aprendizado, social, (...) como é você aqui dentro da escola. Lá fora já tem tanta gente mandando nele. Se eu tento mais, eu não ia conseguir nada dele. Absolutamente nada. Daí pra frente esse menino foi assim um colaborador incrível. Colaborador em instalação. Entendia de fiação, dessa parte de...como não aproveitar. Lógico que eu ia perceber isso? Se eu tenho na mão uma forma de educar com o trabalho dele de artes, de conserto...então ele passou a me atender de uma maneira assim feliz, você sentia nele o prazer. (...) . Mas se o ódio dele pela autoridade é tão grande, você aí precisaria de um tratamento, de toda uma equipe, dos professores, porque eu só...... de uma escola que pudesse dar esse atendimento, eu só, porque ele tava confiando em mim. (Entrevista 11)

As duas passagens mostram uma mesma relação entre o afeto e a autoridade. Nelas, afeto e autoridade são opostos em sua natureza, porém capazes de desempenhar a mesma função: conter a agressividade dos alunos. $\mathrm{O}$ afeto se manifesta essencialmente na disposição para "conversar" e no estabelecimento de um vínculo de "confiança", que vêm substituir a norma impessoal e a hierarquia dos cargos. Na primeira passagem, ao "falar com o coração", a professora deixa de ser a autoridade e passa a ser o "vínculo de família". $\mathrm{Na}$ segunda, o aluno "agrediu a direção, a autoridade que eu representava", mas em seguida, mediante o estabelecimento de uma conversa, passa a confiar e com isso a atender à professora de maneira "feliz".

O ponto a destacar aqui é que o afeto parece ser capaz de, em casos-limite de rejeição radical das formas burocráticas da autoridade representadas pelas normas escolares e suas atribuições funcionais, se constituir em via de imposição dessas mesmas normas, em uma forma de assujeitamento do aluno a essa autoridade. Estamos, assim, diante de um paradoxo: a ausência de afeto e vínculos no ambiente externo à escola é apontada como causa do estabelecimento de uma rejeição radical da autoridade legal da instituição escolar, com sua restauração se dando, justamente, pela introdução do afeto em uma relação permeada, ao menos em seus contornos formais, por uma forma de autoridade que se define pela ausência de afeto. Esses relatos nos sugerem, assim, uma forma particular de relação entre afeto e autoridade, em que o afeto surge como uma condição de possibilidade para o exercício da autoridade.

\section{À Guisa de conclusão: a prática docente e} o par autoridade-afeto na teoria social clássica

A relação entre autoridade e afeto foi tematizada em dois textos clássicos de teoria social: em Economia e Sociedade, no bojo da tipologia das formas da dominação, por Max Weber (1999 [1922]), e em Sexo e Repressão na Sociedade Selvagem, em articulação com as formas de socialização infantil suscitadas pelas diferentes concepções da descendência, por Bronislaw Malinowski (1973 [1927]).

Weber define dominação como "a probabilidade de encontrar obediência para ordens específicas (ou todas) dentro de determinado grupo de pessoas" (1999: 139) e elenca três formas da autoridade: legal, tradicional e carismática. $\mathrm{O}$ autor descreve assim a dominação burocrática:

“...a dominação da impessoalidade formalista: sine ira et studio, sem ódio e paixão, e portanto, sem "amor" e "entusiasmo", sob a pressão de simples conceitos de dever, sem considerações pessoais, 
de modo formalmente igual para 'cada qual', isto é, cada qual dos interessados que efetivamente se encontram em situação igual - é assim que o funcionário ideal exerce seu cargo". (1999: 147)

Em sua tipologia, o espaço do afeto parece ser aquele da dominação carismática, definida como uma "relação comunitária de caráter emocional" (p. 159). Essa seria uma relação na qual há "confiança no líder", cujas qualidades são reconhecidas por meio de "uma entrega crente e inteiramente pessoal nascida do entusiasmo ou da miséria e esperança" (p. 159).

Uma outra forma de dissociação entre autoridade e afeto aparece na discussão empreendida por Malinowski sobre os direitos materno e paterno. Para ele, a cultura exige que a família realize "um processo de educação no qual a ternura, o amor e o cuidado dos pais já não são mais suficientes" (1973: 210). O elemento que vem substituir o afeto e colocar em prática a socialização é, justamente, a autoridade.

Para o autor, a natureza quase incompatível entre afeto e autoridade aparece com clareza na seguinte passagem:

\footnotetext{
"Não há necessidade talvez de desenvolver este ponto, de mostrar como é difícil unir a confiança com os poderes repressivos, a ternura com a autoridade, a amizade com o domínio (...) Também aqui não é fácil a formação da relação, que, partindo do fundamento inicial de ternura e de resposta eficiente, tem de transformar-se em atitude de repressão". (p. 213)
}

$\mathrm{Na}$ construção de Malinowski, o gênero desempenha um papel crucial nessa "divisão do trabalho" entre o afeto e a autoridade, com o masculino tornando-se gradualmente "o princípio da força, da distância, da procura da ambição e da autoridade" (p. 211). Mas, para ele, essa associação entre feminino-ternura e masculino-autoridade não guarda uma correspondência estrita entre as figuras da mãe e do pai, podendo ganhar uma configuração mais complexa - e, para os propósitos desse texto, mais rica - em função da concepção de descendência linear da sociedade em questão.

$\mathrm{O}$ direito paterno seria, para Malinowski, uma formação de perigo potencial, uma vez que conjuga afeto e autoridade em uma mesma figura masculina. Já no direito materno, esses dois elementos estariam dissociados, sendo distribuídos por duas figuras masculinas - o pai e o irmão da mãe. Essa seria a configuração afetoautoridade no direito materno:

\begin{abstract}
"Mas a autoridade masculina não é necessariamente a do pai. (...) Nas sociedades em que a autoridade está nas mãos do tio materno o pai pode continuar a ser o ajudante doméstico e o amigo de seus filhos. O sentimento do pai para com os filhos pode desenvolver-se simples e diretamente. As primeiras atitudes infantis amadurecem gradativa e continuamente com os interesses da adolescência e da maturidade. $O$ pai na vida mais tarde desempenha um papel em grande parte semelhante ao que tem no limiar da existência. A autoridade, a ambição tribal, os elementos repressivos e medidas coercitivas estão associados com outro sentimento, centralizam-se em torno da pessoa do tio materno e se constituem ao longo de linhas inteiramente diferentes". (p. 212)
\end{abstract}

A par da enorme distância temática entre as discussões propostas por Weber e Malinowski, podemos sublinhar um problema comum: a dissociação entre afeto e autoridade. Em Weber, a ausência do afeto praticamente define, como vimos, a forma da dominação na qual poderíamos classificar a autoridade exercida por professores e diretores no ambiente escolar; em Malinowski, afeto e autoridade parecem não poder coexistir, com a ternura sendo incompatível com a "repressão" exigida pelos processos educativos. Aqui, o direito materno, ao introduzir o irmão da mãe como figura de autoridade, se por um lado complica a questão do ponto de vista fenomênico, por outro a torna cristalina do ponto de vista teórico, acentuando a incompatibilidade entre afeto e autoridade.

À luz dessas considerações, como fica então o exercício da autoridade docente? Que balanceamento realiza entre a autoridade e o 
afeto?

O conjunto de histórias narradas na última seção sugere que o afeto pode ser um recurso para o exercício da autoridade, em vez do seu avesso conceitual (como na tipologia de Weber) ou do seu antagonista, aquilo que deve ceder o lugar para a emergência da autoridade (como nas reflexões de Malinowski).

Mas as dificuldades da autoridade docente nos sugerem ainda uma outra forma de nuançar essa relação entre afeto e autoridade. Vejamos uma última história.

A professora conta que, em dado período de sua vida profissional, quando exercia o cargo de diretora de uma escola, teve que lidar com a coexistência de alunos pertencentes a três facções ligadas ao tráfico de drogas. Em uma dada ocasião, um rapaz tentou entrar com um "embrulho" na escola. Ela o impediu, dizendo:

Aí eu chamei e conversei com ele e eu disse que não: você não pode, aqui na escola nem o Presidente da República entra sem passar pelo gabinete. Gabinete do diretor. O presidente da República se quiser entrar na escola o primeiro lugar que ele vai é no gabinete do diretor. Porque mesmo ele sendo presidente da República e ele querendo entrar, é ético ele passar. Eu estar recebendo o presidente. Então você não vai subir. (Entrevista 11)

Dois dias depois, o rapaz retorna à escola. Ela o encontra com uma mochila e o interpela, ao que ele responde:

Aí ele disse que ia entregar. Que eu não era ninguém pra mandar nele. Eu disse: mesmo, eu sou a diretora da escola. Esse ninguém que você está falando eu não sou, eu sou a diretora da escola. Isso eu fui tentando colocá-lo pra beirada, porque ele entrou no segundo andar né. Aí eu fui conversando com ele e ele foi se afastando porque ele ficou com medo que eu fosse tirar o embrulho dele né. Aí ele foi pra beira da escada. Aí eu consegui fazer ele ficar na beira da escada. Aí eu disse: agora eu vou te dizer uma coisa, primeiro eu vou te pedir pra descer. Você faz o favor de descer. "Já te falei mulher que eu não vou descer", isso na maior agressividade. (...)
Aí eu disse: agora - isso olhando olho no olho agora eu tou te mandando descer. Aí ele falou um palavrão e "não vou descer". Aí eu falei mais baixo: agora, eu vou te jogar lá embaixo. Aí parti pra cima dele. (...). Aí ele saiu gritando: "bem que disseram que essa mulher era maluca. Ela é maluca”. Mas eu ia jogar ele lá embaixo mesmo. Porque eu tinha toda certeza que ele tava né. Que era. Eu não sei o que ia dar, mas também eu não podia nem pensar. Era uma escola com quinhentos e tantos alunos e eu vou tá pensando? Tenho que pensar é nos meus alunos isso sim. E não pensar num cara que tá ali tentando. (Entrevista 11)

A história termina com a professora nos contando que, após esse episódio, pediu transferência da escola.

Quer dizer: não estamos diante de uma bravata. Ela teve medo, o que, segundo Miller (2000), faz parte da "psicologia da coragem". Mas de onde essa professora tirou a coragem de ameaçar fisicamente um traficante, sozinha, desarmada? Ou, colocando de outra forma, por que fez isso?

A história começa por um relato em que sua autoridade como diretora da escola é desafiada. Ela o chama para conversar e afirma contundentemente a autoridade que o cargo lhe confere sobre o espaço escolar: ali, "nem o presidente da República". Na ocasião seguinte, ele a desafia negando explicitamente a autoridade do cargo: "ela não é ninguém para mandar nele". Ela revida com o cargo: é a "diretora da escola”. E vai num crescendo: um "pedido", um "favor", uma "ordem", uma "ameaça".

O próprio Searle dificilmente conceberia um exemplo melhor para explicar o que é o ponto de um ato ilocucionário diretivo e a importância de atentarmos para as diferenças de força. Ela vai em um crescendo, até impor sua autoridade a ele, que acaba fazendo o que ela pede/ exige e se retira da escola.

Mas: onde está o afeto aqui? Se estamos discutindo a relação entre afeto e autoridade no ambiente escolar e no exercício da prática docente, qual o trabalho teórico que essa história que termina com uma ameaça de agressão física 
- não contra a diretora, mas por ela - tem a fazer em nosso argumento?

Nos outros relatos, a autoridade é exercida por meio do afeto. Aqui, ela é exercida por causa do afeto. Proteger seus alunos é o que faz essa professora, sozinha, ameaçar fisicamente um traficante.

A autoridade docente nos dá, assim, caminhos alternativos para se pensar em maneiras de associar afeto e autoridade, problematizando suas alocações em campos opostos feitas por dois de seus maiores teóricos em meio aos clássicos da teoria social. Ora como meio, ora como motivação, esse conjunto de histórias de professores e suas agruras no ambiente escolar nos sugere que pode haver mais coisas entre o afeto e a autoridade do que supõe nossa vã teoria social.

\section{Referências bibliográficas}

BOMENY, Helena.; COELHO, Maria Claudia.; SENTO-SÉ, João Trajano. "Violência nas Escolas Públicas do Rio de Janeiro: notas exploratórias sobre a autoridade docente $\mathrm{e}$ as percepções da violência”. In: SEBASTIÃO, João. (Org.). Violência na Escola - tendências, contextos, olhares. Golegã: Editorial Cosmos, 2010, p. 273-322.

CARDOSO DE OLIVEIRA, Luís R. Direito legal e insulto moral: dilemas da Cidadania no Brasil, Quebec e EUA. Rio de Janeiro: Relume Dumará, 2002.

COELHO, Maria Claudia. "Lágrimas com Farinha: percepções femininas da violência em Belém do Pará". In: SENTO-SÉ, João Trajano. (Org.). Segurança Pública - outros olhares, novas possibilidades. Brasília: Secretaria de Políticas Públicas para a Mulher, 2009.

COELHO, Maria Claudia.; PARDO, Johana. "O Pátio do Recreio: interação, bullying e gramáticas emocionais da vitimização”. Dilemas, vol 11, n. 3, 2018, p. 533-561.

COELHO, Maria Claudia.; SENTO-SÉ,
João Trajano; SILVA, Anderson.; ZILLI, Bruno. "Autoridade policial, riso e polidez - notas sobre interações entre polícias e cidadãos na operação Lei Seca no Rio de Janeiro”. Análise Social, v. 209, 2013, p. 900-920.

DÉBARBIEUX, Éric. "A Violência na Escola Francesa: 30 anos de construção social do objeto (1967 - 1997)". Educação e Pesquisa, São Paulo, vol. 27, no. 1, p. 163-193, jan./jun. 2001.

MALINOWSKI, Bronislaw. Sexo e Repressão na Sociedade Selvagem. Petrópolis: Vozes, 1973 [1927].

MILLER, William Ian. The Mystery of Courage. Cambridge: Harvard University Press, 2000.

ROLIM, Marcos. Bullying - o pesadelo da escola. Um estudo de caso e notas sobre o que fazer. Dissertação (Mestrado em Sociologia) - Programa de Pós-Graduação em Sociologia, UFRGS, Rio Grande do Sul, 20018.

SIMIÃO, Daniel Schroeter. "Representando Corpo e Violência: a invenção da 'violência doméstica' em Timor-Leste”. RBCS, vol. 21, no. 61, 2006, p. 133-145.

SEARLE, John R. "A Classification of Illocutionary Acts". Language in Society, vol. 5, no. 1, 1976, p. 1-23.

SOARES, Luiz Eduardo e CARNEIRO, Leandro Piquet. "Os Quatro Nomes da Violência: um estudo sobre éticas populares e cultura política”. In: L. E. Soares et allii. Violência e Política no Rio de Janeiro. Rio de Janeiro: Relume-Dumará: ISER, 1996.

WEBER, Max. Economia e Sociedade. Brasília: Editora da UnB, 1999 [1922].

ZALUAR, Alba. "Um Debate Disperso: violência e crime no Brasil da redemocratização". São Paulo em Perspectiva, 13 (3), 1999, p. 3-17. 